\title{
Molecules linked to Ras signaling as therapeutic targets in cardiac pathologies
}

Manuel Ramos-Kuri ${ }^{1,2,3}$, Sri Harika Meka ${ }^{4}$, Fabio Salamanca-Buentello ${ }^{5}$, Roger J. Hajjar ${ }^{6}$, Larissa Lipskaia ${ }^{7}$ and Elie R. Chemaly ${ }^{4^{*}}$

\begin{abstract}
The Ras family of small Guanosine Triphosphate (GTP)-binding proteins (G proteins) represents one of the main components of intracellular signal transduction required for normal cardiac growth, but is also critically involved in the development of cardiac hypertrophy and heart failure. The present review provides an update on the role of the $\mathrm{H}$-, K- and $\mathrm{N}$-Ras genes and their related pathways in cardiac diseases. We focus on cardiac hypertrophy and heart failure, where Ras has been studied the most. We also review other cardiac diseases, like genetic disorders related to Ras. The scope of the review extends from fundamental concepts to therapeutic applications. Although the three Ras genes have a nearly identical primary structure, there are important functional differences between them: H-Ras mainly regulates cardiomyocyte size, whereas K-Ras regulates cardiomyocyte proliferation. N-Ras is the least studied in cardiac cells and is less associated to cardiac defects. Clinically, oncogenic H-Ras causes Costello syndrome and facio-cutaneous-skeletal syndromes with hypertrophic cardiomyopathy and arrhythmias. On the other hand, oncogenic K-Ras and alterations of other genes of the Ras-Mitogen-Activated Protein Kinase (MAPK) pathway, like Raf, cause Noonan syndrome and cardio-facio-cutaneous syndromes characterized by cardiac hypertrophy and septal defects. We further review the modulation by Ras of key signaling pathways in the cardiomyocyte, including: (i) the classical Ras-Raf-MAPK pathway, which leads to a more physiological form of cardiac hypertrophy; as well as other pathways associated with pathological cardiac hypertrophy, like (ii) The SAPK (stress activated protein kinase) pathways p38 and JNK; and (iii) The alternative pathway Raf-Calcineurin-Nuclear Factor of Activated T cells (NFAT). Genetic alterations of Ras isoforms or of genes in the Ras-MAPK pathway result in Ras-opathies, conditions frequently associated with cardiac hypertrophy or septal defects among other cardiac diseases. Several studies underline the potential role of $\mathrm{H}$ - and K-Ras as a hinge between physiological and pathological cardiac hypertrophy, and as potential therapeutic targets in cardiac hypertrophy and failure.
\end{abstract}

\section{Highlights}

- The Ras (Rat Sarcoma) gene family is a group of small G proteins

- Ras is regulated by growth factors and neurohormones affecting cardiomyocyte growth and hypertrophy

- Ras directly affects cardiomyocyte physiological and pathological hypertrophy

- Genetic alterations of Ras and its pathways result in various cardiac phenotypes

\footnotetext{
*Correspondence: echemaly@buffalo.edu

${ }^{4}$ Division of Nephrology, Department of Medicine, Jacobs School of Medicine and Biomedical Sciences, State University of New York at Buffalo, Clinical and Translational Research Center, 875 Ellicott Street, Suite 8030B, Buffalo, NY 14203, USA
}

Full list of author information is available at the end of the article permits use, sharing, adaptation, distribution and reproduction in any medium or format, as long as you give appropriate credit to the original author(s) and the source, provide a link to the Creative Commons licence, and indicate if changes were made. The images or other third party material in this article are included in the article's Creative Commons licence, unless indicated otherwise in a credit line to the material. If material is not included in the article's Creative Commons licence and your intended use is not permitted by statutory regulation or exceeds the permitted use, you will need to obtain permission directly from the copyright holder. To view a copy of this licence, visit http://creativecommons.org/licenses/by/4.0/. The Creative Commons Public Domain Dedication waiver (http://creativeco mmons.org/publicdomain/zero/1.0/) applies to the data made available in this article, unless otherwise stated in a credit line to the data. 
- Ras and its pathway are differentially regulated in acquired heart disease

- Ras modulation is a promising therapeutic target in various cardiac conditions.

Keywords: Ras-opathies, H-Ras gene, K-Ras gene, Ras pathway, Physiological hypertrophy, Pathological hypertrophy, MAP kinase, Calcineurin

\section{Introduction}

The Ras (Rat sarcoma) family of small G (Guanosine Triphosphate (GTP)-binding) proteins is composed of enzymes that hydrolyze GTP into GDP and represents a critical component of intracellular signal transduction [1]. Ras genes are ubiquitously expressed. Mostly known in cancer biology, these proteins are essential for cellular growth, differentiation and survival of many cell types $[1,2]$.

The Ras superfamily comprises more than a hundred cellular proteins, and is divided into five main families: Ras, Rho, Ran, Rab and Arf GTPases, depending on their genetic sequence, structure and function [3]. The Ras family is then divided into six subfamilies: Ras, Ral, Rit, Rap, Rheb, and Rad. The present review focuses on the role of the Ras subfamily in cardiac cells. There are three main human Ras genes, H-Ras, K-Ras and N-Ras. These genes are proto-oncogenes, and their mutated versions are responsible for neoplastic transformation; they are the most frequently mutated genes in all cancer types [3, 4]. In 1993, Thorburn et al. showed that $\mathrm{H}$-Ras-Val12, an oncogenic mutant of H-Ras, induced hypertrophy of rat neonatal cardiomyocytes in vitro without oncogenic transformation [5]. The role of intracellular pathways involving small $G$ proteins, including Ras, Rho and Rac, in cardiac hypertrophy is well established, as detailed in previous reviews [1, 2, 6-9]. The present review provides an update on the role of the Ras subfamily and its related pathways in cardiac diseases, mainly cardiac hypertrophy and heart failure (HF), where it has been widely studied, but also in genetic disorders of $\mathrm{H}$ - Ras, K-Ras, and N-Ras genes. The scope of this review extends from fundamental concepts to therapeutic applications.

\section{Molecular biology of the Ras subfamily Small $\mathrm{G}$ proteins}

The role of small $G$ proteins in signaling cardiac hypertrophy initiated by G-protein coupled receptors (GPCR) is well demonstrated [2]. Small G proteins act as a molecular switch, inactive in Guanosine Diphosphate (GDP)-bound state and active in Guanosine Triphosphate (GTP)-bound state, in which GTP induces a conformational change, subsequently activating downstream intracellular signaling pathways (Fig. 1) [1, 2, 7].

The spontaneous molecular switch activity of small G proteins is inefficient and is amplified by Guanine nucleotide exchange factors (GEFs) and reduced by GTPaseactivating proteins (GAPs) (Fig. 1) [1, 2]. GEF activates Ras by exchanging GDP for GTP while GAP enhances GTP hydrolysis to GDP by accelerating the slow intrinsic GTPase activity of Ras; thus, GEF and GAP provide additional levels of modulation of the action of small $\mathrm{G}$ proteins [2]. Active Ras (GTP-bound) binds with high affinity to several molecular effectors through which it exerts its pleiotropic effects (Fig. 1) [10]. Signal transduction from the cell surface to the nucleus through Ras involves various and complex pathways, exerting diverse and even opposite effects such as cell proliferation or growth arrest, senescence or differentiation, apoptosis or survival $[6,10,11]$. The end-result of these pleiotropic effects of Ras depends on many factors such as cell type and gene expression pattern. For example, the Ras-related signaling pathways leading to cardiac hypertrophy and remodeling can be induced by $\alpha$-adrenergic stimulation [12], among many other ligands (Fig. 1); and slight changes in the concentration of the $\alpha$-adrenergic agonist phenylephrine (PE) can exert proliferative or anti-proliferative effects [13]. The role of Ras in transducing mechanical stimuli is more controversial $[14,15]$.

\section{The Ras gene subfamily in the heart}

The three human Ras genes H-Ras, N-Ras, and K-Ras encode four isoforms of the Ras subfamily: H-Ras, N-Ras, and $\mathrm{K}-$ Ras $4 \mathrm{~A}$ and $\mathrm{K}-\mathrm{Ras} 4 \mathrm{~B}$, the latter two resulting from alternative splicing of the fourth coding exon 5 of the K-Ras gene [16]. To our knowledge, this alternative splicing of K-Ras has not been studied in cardiac cells.

Ras genes are very similar in primary protein structure but functionally different [17]. Their gene codes for a 189 amino acids protein, and the main difference between them is in the 25 amino acids at the carboxyl end. This carboxyl-terminal region is known as the hypervariable region of Ras, and is the essential signal for the localization of Ras isoforms to different micro-domains at the 


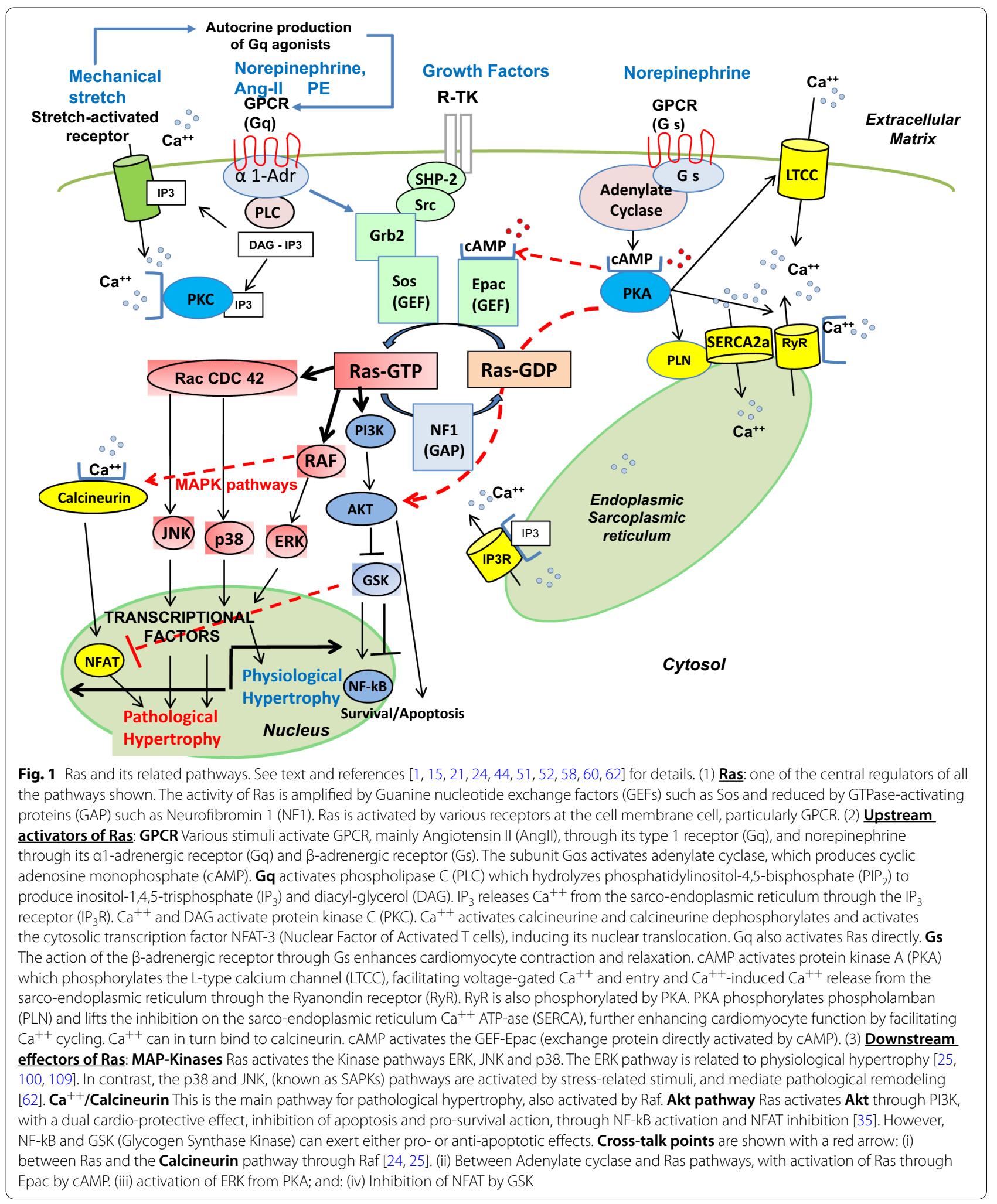


inner surface of the cellular membrane [18]. This hypervariable region bears very little identity between the Ras isoforms, as little as $15 \%$, and contains the important CAAX box $(\mathrm{C}=$ cysteine, $\mathrm{A}=$ apolar amino acid and $\mathrm{X}=$ serine or methionine) in the carboxyl end of the protein, where the farnesyl lipid is attached $[18,19]$.

\section{Physiological and pathological cardiac hypertrophy}

Cardiac hypertrophy is a heterogeneous set of phenomena $[2,20]$. It includes physiological hypertrophy resulting from normal cardiac growth or a response to aerobic exercise and pregnancy [21]. Physiological hypertrophy is adaptive and enhances cardiac structure and function $[2,9,20]$. On the other hand, pathological hypertrophy, which may be initially adaptive and subsequently maladaptive, occurs in response to stressors such as hypertension, excess mechanical loading caused by structural lesions, or mutations in genes encoding sarcomeric proteins. Pathological hypertrophy progresses towards HF, with fibrosis and arrhythmias, when sustained [2].

When faced with a pro-hypertrophic stimulus, the myocardium remodels structurally and molecularly within a spectrum of responses between the extremes of either physiological or pathological hypertrophy [21, 22]. In a comparative study of pressure and volume overload left ventricular hypertrophy and failure, we have demonstrated an association of the propensity for ischemia to myocardial fibrosis, suggesting that oxygen supplydemand imbalance may drive the myocardium to pathological hypertrophy [23].

\section{Role of $\mathbf{H}-$, K- and $\mathbf{N}$ Ras in cardiac hypertrophy $\mathrm{H}$-Ras in cardiac hypertrophy}

As previously mentioned, pioneering studies of oncogenes in cardiomyocytes in vitro showed that oncogenic H-Ras induced hypertrophy [5]. In contrast to the effects of such mutants on other cell lineages, they did not activate malignant transformation of cardiomyocytes, but instead induced cardiac hypertrophy the with expression of classical markers of pathological hypertrophy such as Atrial Natriuretic Factor (ANF), Skeletal Muscle $\alpha$ Actin (SkM- $\alpha$ Actin), $\beta$-Myosin Heavy Chain $(\beta-M H C)$ and c-Fos in neonatal cardiomyocytes in vitro $[5,14,15]$.

The central role of H-Ras in pathological cadiac hypertrophy resides in the activation of several pathways, such as the transcriptional effects of the activation of the Ras/ Raf/MEK/MAPK pathway (see "Abbreviations"-MAPK, Mitogen-Activated Protein Kinase and MEK, MAPKK (MAP kinase kinase) that activates a MAPK, extracellular signal-regulated protein kinase (ERK), or the Calcineurin/Nuclear Factor of Activated T cells (NFAT) pathway
[1]. These pathways lead to a decrease in the expression of the sarcoplasmic reticulum calcium ATPase 2a (SERCA2a), thus promoting pathological cardiomyocyte hypertrophy [1].

The normal isoform of $\mathrm{H}$-Ras stimulates a physiological form of cardiac hypertrophy, through the ERK pathway, while its oncogenic mutant H-Ras-Val12 (constitutive active) stimulates pathological hypertrophy through the Calcineurine/NFAT pathway [24, 25]. Also, the mechanism and pattern of phosphorylation or auto-phosphorylation of ERK1/2 can lead to either physiological or pathological cardiac hypertrophy $[20,26]$.

\section{$H$-Ras and the cardiomyocyte structure}

The effect of Ras-Val12 on the sarcomeric structure of neonatal cardiomyocytes in vitro has been controversial, since two independent studies reported that Ras-Val12 induced hypertrophy with enhanced or unchanged sarcomeric organization $[5,27]$, while other in vitro studies showed that Ras-Val12 caused myofibrillar disorganization [25], or reduced myofibrillar density [28]. Also, in transgenic mice, the active mutant H-Ras-Val12 caused obstructive hypertrophy with myofibrillar disarray, similar to hypertrophic cardiomyopathy (HCM) [29, 30], or severe hypertrophy with diastolic dysfunction [27, 30]. In line with this, Zheng et al. found that transgenic mice overexpressing H-Ras-Val12 under control of an $\alpha$-MHC promoter, developed postnatal and lethal HF [27]. At the cellular level, H-Ras-Val12 induced several HF-related phenomena: i) it reduced the L-type $\mathrm{Ca}^{++}$channel current, and sarcoplasmic reticulum $\mathrm{Ca}^{++}$uptake [25]; ii) it reduced the expression of SERCA2a and the phosphorylation of phospholamban, leading to diastolic dysfunction [27].

Furthermore, the expression of H-Ras is increased in the myocardium of patients with genetic HCM secondary to $\beta$-myosin heavy chain or troponin $\mathrm{T}$ mutations [31]. Importantly, the hypertrophic process initiated by Ras-Val12 can be reversed: suppression of an inducible promoter on H-Ras-Val12 reverses the associated cardiomyopathy [32].

\section{Cardiac role of K-Ras}

Relatively few studies have investigated K-Ras in the heart, but it is clearly linked to cardiac cell proliferation. The first observation in this way was in the ${\mathrm{K}-\mathrm{Ras}^{-1-}}^{-1}$ knock-out mice, which die on embryonic day 15.5 with extremely thin left ventricular walls [33]. The proliferative role of K-Ras in cardiac cells was corroborated in mice with active mutant K-RasV14I, which causes cardiac enlargement secondary to cardiomyocyte hyperplasia (increased number of cells) without cardiomyocyte hypertrophy [34]. This proliferative role of K-Ras is also 
observed in other tissues: mutations of K-Ras are associated with $25-30 \%$ of all cancers, versus $3 \%$ for $\mathrm{H}$-Ras and $8 \%$ for N-Ras [4]. Interestingly, when K-Ras is only partially down-regulated in heterozygous $\mathrm{K}-\mathrm{Ras}^{ \pm}$mice, the heart is normal at birth, with even improved structure and function under pressure overload [35].

The underliying mechanism of this differential function between H-Ras (hypertrophy) and K-Ras (proliferation) in cardiac cells is not known, to our knowledge. In colorectal cancer cells, for example, K-Ras sustains cell proliferation through $\mathrm{p} 38$, even when MEK1/2 and ERK1/2 are inhibited with inhibitory RNAi [36].

\section{$\mathrm{N}$-Ras and the heart}

Among genes of the Ras subfamily, N-Ras appears to have the least functional importance in the heart. The cardiac role of N-Ras is not yet clearly determined, although active mutations of $\mathrm{N}$-Ras cause Noonan syndrome, or Ras-opathies, but much less frequently than $\mathrm{H}$ - or K-Ras mutations [37]. Patients with Noonan syndrome and $\mathrm{N}$-Ras mutations also present congenital heart defects like HCM or pulmonary stenosis [37].

\section{Differences and similitudes between Ras isoforms Microdomain localization}

Ras isoforms have a very similar protein structure. Functional differences between Ras isoforms are due, at least in part, to their localizations at different domains of the plasma membrane. H-Ras is equally localized in caveolae, lipid rafts and disorganized membrane. K-Ras4A is localized preferentially in disorganized nonraft plasma membrane. K-Ras4B is directly shuttled to the plasma membrane, thanks to a specific polybasic lysine-rich sequence at its carboxyl-terminal region [38, 39]. Finally, $\mathrm{N}$-Ras localizes to caveolin-positive and caveolin-negative domains [18, 39]. However, to our knowledge, these subcellular localization differences have not been studied in cardiac cells.

\section{Compensatory functions between Ras isoforms}

The functions of the three genes of the Ras subfamily in the heart are mutually compensatory, as shown in a few examples. H-Ras ${ }^{-1-}$ and N-Ras ${ }^{-1-}$ knock-out mice have a normal phenotype; even mice with a double knockout, $\mathrm{H}-\mathrm{Ras}^{-1-}$ plus N-Ras ${ }^{-1-}$, have a normal phenotype including a normal heart [40, 41]. This compensatory function between Ras genes is further supported by evidence from a knock-in model, in which the H-Ras coding sequence replaces the $\mathrm{K}-\mathrm{Ras}^{-/-}$locus; even in a triple knock-out mouse (H-Ras ${ }^{-1-}, \mathrm{K}-\mathrm{Ras}^{-1-}$ and $\mathrm{N}-\mathrm{Ras}^{-1-}$ ), the knock-in H-Ras supplies the Ras function resulting in normal embryonic development [41, 42]. However, the adult mice of this $\mathrm{H}$-Ras knock-in model developed a dilated cardiomyopathy due to high systolic and diastolic blood pressure, suggesting that K-Ras is the only absolutely required for normal cardiovascular function [41, 42].

Despite these similitudes and complementarities between them, Ras isoforms are not functionally redundant $[18,38]$, as illustrated by the different cardiac phenotypes seen in Ras-opathies, depending on the affected Ras isoform, as reviewed and described elsewhere [1, 37, 43].

\section{Ras-related network in cardiomyocytes}

The Ras signaling network connects signals from several extracellular receptors to intracellular signaling pathways and, in turn, activates multiple downstream effectors, resulting in a variety of metabolic effects.

Extracellular receptors linked to the Ras network include various tyrosine-kinase receptors ((Epidermal Growth Factor (EGF), Platelet-Derived Growth Factor (PDGF), among others) and GPCRs (Fig. 1).

\section{Receptor tyrosine kinases (RTKs)}

Various polypeptidic growth factors, cytokines and hormones bind to the extracellular domain of a RTK, activating the RTK cytoplasmic kinase domains. This allows a tyrosine in the cytoplasmic portion of each receptor monomer to be trans-phosphorylated by its partner receptor, leading to activation of downstream signal transduction pathways, such as the Ras/MAPK signaling cascade.

\section{Ras adaptor proteins}

RTK activate Ras through adaptor proteins including SHP-2, Src, and Grb2 [1, 44] (Fig. 1). Importantly, more than $50 \%$ of patients with Noonan syndrome display a pathogenic mutation in the PTPN11 gene encoding SHP-2 protein [7]. In line with this, Thorburn et al. [5] reported that, in cardiomyocytes, the active mutant of Src-F527 activated H-Ras and induced cardiac hypertrophy.

\section{Positive and negative regulation of Ras}

As mentioned earlier, the activity of Ras is positively regulated through GEFs. Examples of GEFs include Son of sevenless (Sos) and the Exchange Protein directly Activated by cyclic adenosine monophosphate (cAMP) (Epac). Mutations of the GEF Sos are associated with Noonan Syndrome [1]. Ras is negatively regulated through GAPs, like neurofibromin 1 (NF1) [2]. GAPs terminate Ras signaling by binding to the activated $G$ proteins to stimulate their GTPase activity. The two most studied GAPs in the Ras pathway are NF1 and Carabin 
[45-49]. Total NF1 deletion in mice results in hyperproliferation of the cardiac outflow tract, with redundant tissue at the endocardial cushions [47]. Mice with specific loss of NF1 in the heart developed marked cardiac hypertrophy in adult life, with progressive dilated cardiomyopathy and fibrosis [49]. Similarly, total deletion of carabin in mice promotes the development of major cardiac hypertrophy in a pressure overload model [45].

\section{G-Protein Coupled Receptors (GPCRs)}

There are two major signaling transduction pathways involving the GPCRs: the cAMP signaling pathway (Gos -coupled receptors) and the phosphatidylinositol signaling pathway (Goq/ ${ }_{11}$-coupled receptors).

\section{cAMP signaling pathway}

In cardiomyocytes, the cAMP signaling pathway is coupled to the activation of the $\beta$-adrenergic receptors $(\beta-A R)$ by catecholamines (Fig. 1). Within the cardiomyocyte, cAMP activates the cAMP-dependent protein kinase A (PKA), inducing the phosphorylation of the L-type $\mathrm{Ca}^{++}$channels (LTCCs), the ryanodine receptors/channels (RyRs), and of the negative regulator of SERCA2a phospholamban (PLN), thus amplifying the intracellular calcium transient and mediating strong inotropic, lusitropic and chronotropic responses [50]. The cAMP pathway also activates the exchange protein Epac1 linked to H-Ras signaling (Fig. 1) $[1,51,52]$. Epac1 is upregulated in mouse models of isoproterenol-induced left ventricular hypertrophy, and in models of pressure overload-induced hypertrophy and HF, indicating an important role for Epac1 in pathological cardiac remodeling [53]. The pro-hypertrophic signaling resulting from the stimulation of the $\beta 1$-AR activates the $\beta$-arrestinEpac1 signaling complex including two small GTPases, Rap2 and Ras, as well as the $\mathrm{Ca}^{++} /$calmodulin-dependent protein Kinase II (CaMKII). Upon $\beta_{1}$-AR stimulation, Epac1 activates Ras, Calcineurin, and CaMKII, rather than its classical effector Rap1, leading to cardiac hypertrophy [54]. A dominant negative form of Ras, RasS17N, decreased the effect of Epac1-induced cardiac hypertrophy, highlighting the role of Ras, rather than Rap1, in the $\beta$-AR /cAMP/Epac hypertrophic signaling pathway [54].

\section{Phosphatidylinositol signaling pathway}

In cardiomyocytes, the $G_{\alpha q / 11}$ pathway is mediated by several membrane receptors, including the $\alpha 1$-adrenergic receptor $(\alpha 1-\mathrm{AR})$ activated by catecholamines and the angiotensin-II (AngII) receptor type 1 (AT1R). The effector of the $G_{\alpha q / 11}$ pathway is phospholipase $C$ (PLC), which catalyzes the hydrolysis of membranebound phosphatidylinositol 4,5-bisphosphate ( $\left.\mathrm{PIP}_{2}\right)$ into the second messengers inositol 1,4,5 trisphosphate
$\left(\mathrm{IP}_{3}\right)$ and diacylglycerol (DAG), both of which can affect directly or indirectly plasma membrane or sarcoplasmic $\mathrm{Ca}^{++}$channels such as the $\mathrm{IP}_{3}$ receptor $\left(\mathrm{IP}_{3} \mathrm{R}\right)$, resulting in sustained increase in cytosolic $\mathrm{Ca}^{++}$. DAG and cytosolic $\mathrm{Ca}^{++}$contribute to activation of protein kinase $\mathrm{C}$ (PKC). Elevated intracellular $\mathrm{Ca}^{++}$also activates the prohypertrophic $\mathrm{Ca}^{++} /$calmodulin signaling pathway [55-57]. In cardiomyocytes, catecholamines also activate the $\alpha 1-\mathrm{AR}$, inducing a long-term hypertrophic response mediated by Ras-GTP/MAPK and Ras-GTP/JNK (JNK, Jun $\mathrm{NH}_{2}$-terminal kinase, see "Abbreviations") pathways [6, 11, 58] (Fig. 1).

AngII was also shown to activate directly the Ras-RafMAPK pathway, as well as two other MAPK pathways, JNK and p38 [59]. Indeed, inhibition of AT1R by candesartan abrogates the Ras-Raf-MAPK pathway, and partially downregulates the other two MAPK pathways, JNK and p38 [59, 60]. Antagonizing the actions of AngII is an established therapeutic strategy in patients with cardiac hypertrophy and HF $[21,61]$.

\section{Signaling pathways downstream of Ras}

Ras modulates at least nine downstream signaling pathways; mostly involving MAPK[58]. Three kinase pathways are named after their final kinase: ERK, JNK, and p38 (Fig. 1). Ras also modulates the Akt/mTOR -signaling network and some non-kinase pathways, including the $\mathrm{Ca}^{++} /$Calcineurin pathway [58]. Ras regulates physiological cardiomyocyte growth, mainly through the Ras/ Raf/ERK pathway, and pathological cardiac remodeling through other kinase cascades: JNK, p38 and ERK5, as well as the $\mathrm{Ca}^{++}$signaling pathway $[6,11,22,25,58]$ (Fig. 1).

\section{Ras-MAPK pathways}

Ras is linked to MAPK pathways through Raf, as part of the of the classical Ras/Raf/MEK/ERK1/2 pathway [62].

Exlusive activation of the ERK signaling pathway in cardiomyocytes mediates physiological hypertrophy. Transgenic mice with an activated MEK1 gene with cardiac-restricted expression displayed a physiological form of cardiac hypertrophy and a partial resistance to cardiomyocyte apoptosis [48]. Similarly, expression of dominant negative Raf (DN-Raf-1) in mice has no effect on cardiac function at baseline, but promotes cardiomyocyte apoptosis and increases mortality in the setting of pressure overload [63]. Finally, total ablation of c-Raf-1 in mouse hearts led to dilated cardiomyopathy, even in the absence of external stress [64].

JNK and p38 signaling pathways are also known as the Stress Activated Protein Kinases (SAPK) pathways. These pathways respond to several stressful stimuli like cytokines, the Tumor Necrosis Factor (TNF) and 
interleukin 1, or to physical stimuli like osmolar or oxidative stress, ionizing radiation, or mechanical hypertrophic stimuli, like cellular stretching [8]. Hyperactivation of SAPK plays a critical role in the development of pathological cardiac hypertrophy and HF [48]. Ras can activate the SAPK pathways by Rac1, a small GTPase of the Ras superfamily or by PI3K/AKT/mTOR network.

The role of the Ras/JNK signaling pathway in hypertrophic cardiac remodeling was established in transgenic mice expressing the oncogenic H-Ras-Leu61 mutant [12]. Other studies demonstrated that inhibition of JNK kinase attenuated cardiac hypertrophy in animal models $[60$, $65]$.

The p38 signalling pathway was shown to play a role in apoptosis and hypertrophic remodeling of cardiomyocytes [66]. Several studies pointed to the direct link between Ras and p38 kinases. Indeed, stimulation of rat neonatal cardiomyocytes with PE, AngII or Endothelin-I activates $\mathrm{p} 38$, JNK and ERK [21].

Furtrhermore, dominant negative Ras and the Ras inhibitor manumycin completely inhibited AngII induced ERK activation [67]. AngII induces Ras/ERK activation partially via the $\mathrm{Ca}^{++} /$calmodulin-activated tyrosine kinase PYK2 (proline-rich tyrosine kinase 2), which is involved in $\mathrm{Ca}^{++}$-dependent tyrosine phosphorylation of ERK, and in the binding of GTP to p21 Ras, demonstrating a cross-talk between $\mathrm{Ca}^{++}$and tyrosinekinase signalling pathways [67]. PYK2 activation plays a critical role in the induction of pressure overloadinduced cardiomyocyte hypertrophy [68]. Given the fact that $\mathrm{Ca}^{++}$overload and $\mathrm{Ca}^{++-}$activated signaling pathways are also critically involved in pathological cardiomyocyte remodeling, PYK2 may be a key regulator of at least some signaling pathways leading to the induction of cardiac hypertrophy and its progression to HF [68].

\section{$\mathrm{Ca}^{++} /$Calcineurin/NFAT pathway}

The $\mathrm{Ca}^{++} /$calcineurin signaling pathway plays a central role in pathological cardiac remodeling [57, 62]. Increases in resting intracellular $\mathrm{Ca}^{++}$concentration in cardiomyocytes activates the $\mathrm{Ca}^{++} /$calmodulin regulated phosphatase 2B (calcineurin). Calcineurin dephosphorylates and activates the cytosolic transcription factor NFAT-3, inducing its nuclear translocation [57, 62] (Fig. 1). NFAT is involved in the induction of genes related to hypertrophic cardiomyocyte remodeling, leading to cardiac dysfunction and HF [57, 62] (Fig. 2). The role of Ras in activating the $\mathrm{Ca}^{++} /$calcineurine signaling pathway was demonstrated in animal models with cardiac overexpression of oncogenic active H-Ras [69]. Active mutants of Raf also activate Calcineurin, making Raf a cross-talk point between the Ras/Raf/ERK and the $\mathrm{Ca}^{++} /$Calcineurin pathways [24]. In line with this, several gain-of function mutations of Raf are associated with activation of $\mathrm{Ca}^{++} /$calcineurine signaling and pathological cardiac hypertrophy, as in Noonan and LEOPARD syndromes $[1,24]$.

\section{PI3K/Akt/mTOR signaling network, another important Ras-related pathway}

The PI3K/Akt/mTOR signaling network is a well-known player in cell metabolism, survival and growth $[26,70]$.

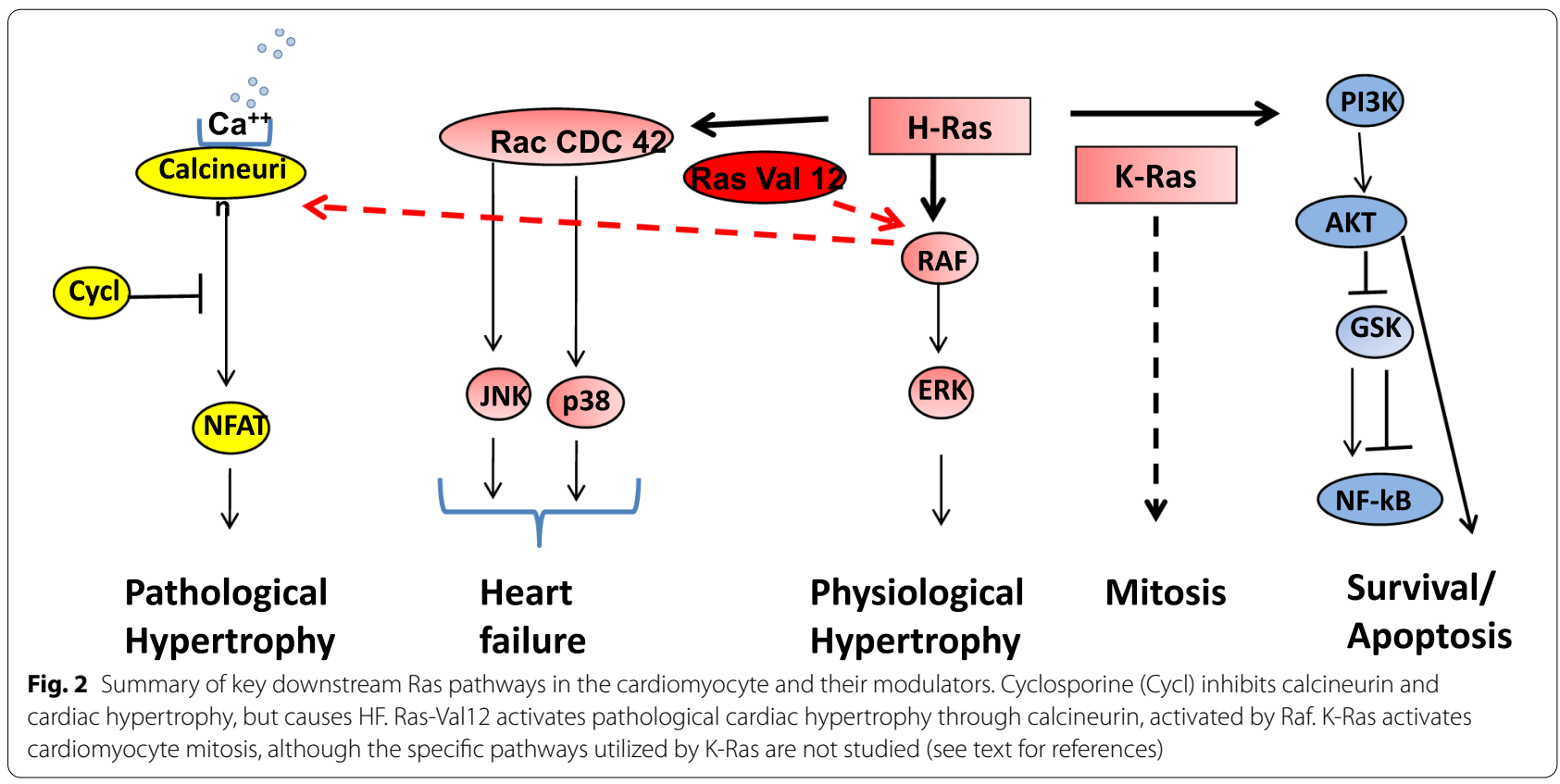


Even though Ras is not referred as a member of the mTOR signaling network, numerous studies, including studies from the Proud laboratory, have established the links between Ras/ERK, Ras/Akt and mTORC1 dependent protein synthesis [35, 58, 66, 71-73] (Fig. 1). Indeed, the Proud group has established that the activation of protein synthesis by the $\alpha 1-\mathrm{AR}$ agonist PE and by endothelin-1 is blocked by the mTORC1 inhibitor rapamycin, indicating that $\mathrm{PE}$ and endothelin-1 activate mTORC1 via Ras/MEK/ERK signaling in cardiomyocytes [71, 72]. Therefore, the expression of constitutively active MEK1 caused activation of protein synthesis in a rapamycin-dependent manner [71, 72]. Another study from this group reported that overexpression of the Ras homolog Rheb in rat cardiomyocytes was sufficient to activate mTOR1 and induced cardiomyocyte growth, but not the expression of markers of pathological remodeling ANF and B-type natriuretic peptide [73], suggesting that exclusive activation of mTORC1 promotes a rather physiological than pathological hypertrophy [73]. The mechanism of the interaction of mTORC1 and Ras/MEK/ERK is not completely understood, but might be related to the inhibition of Akt downstream effector proteins TSC1 and TSC2. The TSC1/2 complex acts as a GTPase -activator protein for the small GTPase Rheb, and Rheb GTP activates mTORC1 signaling [74]. Other effectors regulated by Akt include caspases, glycogen synthase kinase-3
(GSK3) and NF-kB [8, 26, 48, 70]. PI3K/Akt/mTOR is a complex network with several feedback loops, each mediating separate cellular processes, thus, the consequences of experimental Akt activation on cardiac function were variable, depending on experimental conditions. For example, in patients with HF, Akt activation is cardioprotective [75]. Akt was also shown to promote physiological cardiac hypertrophy and, under prolonged stimulation, pathological hypertrophy and HF [34, 76, 77]. Activation of GSK and NF-kB also enhances cardiac cell survival by its anti-apoptotic effect (Fig. 2) [34, $58]$, but can also mediate cardiac hypertrophy [34, 78]. These studies highlight interconnections at several levels between Ras/MEK/ERK and PI3K/Akt/mTOR signaling networtks controling protein synthesis, cardiomyocyte growth and remodeling.

\section{Ras and other cardiac diseases Ras-opathies and the heart}

Several related syndromes known as Ras-opahties are due to germline mutations in genes of the Ras subfamily or in the Ras/Raf/ERK pathway (Fig. 1 and Table 1. These entities involve mutations in more than 20 genes [43], and manifest as heart diseases [79]. Jhang et al. analyzed a series of 155 patients with Ras-opahties, 118 of them had a cardiac anomaly, most commonly pulmonary stenosis, followed by atrial septal defect and HCM [79].

Table 1 Summary of H, K and N-Ras mutants with gain or loss of function, in vitro (cardiomyocytes in culture) and in vivo (rodent models and clinical syndromes)

\begin{tabular}{|c|c|c|}
\hline & Increased function & Decreased function \\
\hline H-Ras & $\begin{array}{l}\text { In vitro: Ras Val12 }[25,28] \text { : } \\
\text { Hypertrophy with sarcomeric disruption } \\
\text { Inhibition of cardiomyocyte beating } \\
\text { In vivo: Ras Val12 in mice }[12,41] \text { : } \\
\text { Hypertrophic cardiomyopathy } \\
\text { H-Ras wild type compensates K-Ras }{ }^{-/-} \text {in mice } \\
\text { Clinical: Costello syndrome }[81] \\
\text { Hypertrophic cardiomyopathy } \\
\text { Arrhythmias }\end{array}$ & $\begin{array}{l}\text { In vitro: DN-Ras [25]: } \\
\text { Enhancement of cardiomyocyte beating } \\
\text { Enhancement of sarcomeric structure } \\
\text { In vivo: experiments of H-Ras inhibition }[25,33] \text { : } \\
\text { DN-Ras favors physiological cardiac hypertrophy in a rat model of } \\
\text { pressure overload } \\
\text { Potential therapy for pathological cardiac hypertrophy and heart } \\
\text { failure }^{\text {H-Ras }}{ }^{-1-} \text { mice: normal heart and offsprings } \\
\text { Clinical: no data }\end{array}$ \\
\hline K-Ras & $\begin{array}{l}\text { In vitro: Active K-Ras V14I in cardiomyocyte [34]: } \\
\text { Increased mitosis } \\
\text { In vivo: K-Ras V14I mice [34]: } \\
\text { Hyperplasia with no hypertrophy } \\
\text { Clinical: Noonan or cardio-facio-cutaneous syndromes [80]: } \\
\text { Hypertrophic cardiomyopathy } \\
\text { Atrial and ventricular septal defects } \\
\text { Pulmonary valve stenosis }\end{array}$ & $\begin{array}{l}\text { In vitro: No data } \\
\text { In vivo: K-Ras }{ }^{-1-} \text { mice }[33,35] \text { : } \\
\text { Very low proliferation of cardiomyocytes, lethal at embryonic day } 15.5 \\
\text { with extremely thin ventricular walls } \\
\text { K-Ras is the only essential gene in the Ras subfamily } \\
\text { K-Ras }{ }^{ \pm} \text {mice: normal at birth and protected in pressure overload } \\
\text { Clinical: no data }\end{array}$ \\
\hline N-Ras & $\begin{array}{l}\text { In vitro: No data on cardiac cells } \\
\text { In vivo: N-Ras G12D mice [110] } \\
\text { Mutated mouse embryos with cardiac malformations mimicking } \\
\text { Noonan Syndrome: ventricular septal defects, double outlet right } \\
\text { ventricle, hypertrabeculated/thin myocardium and pulmonic valve } \\
\text { stenosis } \\
\text { Clinical: Noonan syndrome-some cases [37] }\end{array}$ & $\begin{array}{l}\text { In vitro: No data } \\
\text { In vivo: N-Ras }{ }^{--1-} \text { mice [33]: } \\
\text { Normal heart, normal offsprings } \\
\text { Clinical: no data }\end{array}$ \\
\hline
\end{tabular}


Noonan syndrome was the first Ras-opathy reported [43], is the second most common syndromic cause of congenital heart disease [80], and is associated with mutated genes in the Ras signaling pathway: SHP2 (PTPN11), SOS1, K-Ras or C-RAF among others. As previously stated, mutations in the PTPN11 gene are present in more than $50 \%$ of patients with Noonan syndrome [43]. On the other hand, LEOPARD syndrome has been re-classified as Noonan syndrome with lentigines, and is caused by two of the genes causing Noonan syndrome, SHP-2 or B-RAF [43]. At the cardiac level, $66 \%$ of Noonan syndrome patients presented with pulmonary valve stenosis and $14 \%$ with $\mathrm{HCM}[80,81]$.

There is also a significant clinical overlap between cardio-facio-cutaneous (CFC) and Costello syndromes [82]. The CFC syndromes are genetically heterogeneous, with mutated genes downstream of Ras in the Ras-MAPK pathway: K-Ras, BRAF, MAPK1 and MAPK2, BRAF being the most frequently mutated gene [82]. In contrast, Costello syndrome is almost exclusively associated with $\mathrm{H}$-Ras mutations in codons 12 or 13 [82]. Only 44\% of patients with Costello syndrome have congenital heart defects, with valvar pulmonary stenosis, HCM, or atrial tachycardia. Costello syndrome is also associated with a higher risk of malignancies like rhabdomyosarcoma or bladder cancer [83].

Mutations of Ras negative regulator NF1 are associated with characteristic neurofibromas (Schwann cells neoplasms) and cardiac hypertrophy [84]. However, the cardiac phenotype is only present among patients with large NF-1 deletions: a clinical study found that only 6 out of 16 patients with neurofibromatosis had congenital heart disease, and only three of them had cardiac hypertrophy [84].

\section{Ras and heart failure}

HF is a leading cause of sudden death, frequently preceded by pathological cardiac hypertrophy.

Haq et al. compared the activity of five major signaling pathways related to Ras, in hearts of patients with cardiac hypertrophy (secondary to hypertension alone or hypertension and coronary artery disease), versus patients with HF [75]. In that study, kinases pathways (MAPK, p38 and SAPK) showed a low level of activation in hypertrophy, but were highly activated in HF. In contrast, the calcineurin pathway was highly activated in hypertrophy, but to a lesser extent in HF. Finally, the Akt pathway was not active in cardiac hypertrophy, but highly active in HF [75].

\section{Ras and cardiac arrhythmias}

Hypertension is the most common and modifiable risk factor for the development of atrial fibrillation $[85,86]$.
Activation of the renin-angiotensin-aldosterone system in hypertension leads to left atrial enlargement with secondary fibrosis and conduction abnormalities, resulting in atrial fibrillation [87]. A study of hypertensive rats showed that telmisartan was more effective in reducing the arrhythmogenic potential than valsartan at similar blood pressure control. Hypertension activates the Ras-ERK pathway and inhibits the PI3K-Akt-endothelial nitric oxide synthase (eNOS) pathway, causing structural remodeling and atrial arrhythmias. Telmisartan suppressed Ras-ERK signalling and activated PI3K-AkteNOS to a greater extent than valsartan [88]. This in turn led to significantly decreased myocyte size, intersitial fibrosis, apoptotic index and shortened duration of atrial arrhythmia when induced in Telmisartan-treated, spontaneous hypertensive rats [88]. Other studies have shown that the atrial expression ERK1/2 is increased in patients with atrial fibrillation compared with those in sinus rhythm [89].

\section{Ischemic preconditionning and Ras}

Two different experiments have shown that Ras inhibition had a beneficial effect in ischemic preconditioning of the myocardium: one with the farnesyl transferase inhibitor FPT-III [90], and the other one with lovastatin [91]. However, in both cases, the protective effect was observed only when the Ras inhibitor was administered prior to the ischemic event $[90,91]$. When FPT-III was given during re-perfusion, the degree of improvement in left ventricular contractility was significantly less [90]. Lovastatin achieved this effect at the very high dose of $15 \mathrm{mg} / \mathrm{kg}$, close to 100 times higher than the doses used to treat clinical hyper-cholesterolemia.

\section{Modulation of Ras as a possible therapy for cardiac hypertrophy and HF}

A large variety of pharmacological and non-pharmacological therapies are available in HF [61], nonetheless, there remain unmet therapeutic needs for HF as a common and serious condition [92, 93]. The results of cellular and animal studies have highlighted the central role of Ras in the control of numerous signaling pathways involved in physilogical and pathological cardiac remodeling. Thus, molecules linked to Ras signaling are potential therapeutic targets in cardiac pathologies.

\section{Molecular strategies}

The most specific modulator of H-Ras is its dominant negative mutant DN-RasN17, but its clinical use is highly challenging. It attenuates pathological ventricular remodeling (versus physiological) in a rat model of pressure overload hypertrophy, as attested by the decreased expression of pathologic cardiac hypertrophy markers 
ANF and $\beta$-MHC, improved sarcomeric function and enhanced $\mathrm{Ca}^{++}$transient in cardiomyocytes [25]. In spontaneously hypertensive rats, a traditional Chinese medicine suppresses left ventricular hypertrophy through down-regulation of Ras and ERK1/2 expression [94].

\section{Modulation of Ras prenylation}

Addition of a farnesyl molecule to the aminoacid sequence CAAX in the carboxyl end of the Ras protein is a post-translational modification needed to localize Ras at the cell membrane. This prenylation of Ras can be inhibited by statins or by inhibitors of the Farnesyl Transferase, which makes these molecules Ras modulators.

\section{Statins: Inhibition of farnesyl synthesis}

Statins are a group of anti-hypercholesterolemic drugs that inhibit the syntesis of the farnesyl molecule, and have been used to inhibit Ras prenylation and subsequently cardiac hypertrophy in animal models. More precisely, statins inhibit the hydroxymethyl-glutaryl-conezyme A (HMG-CoA) reductase, which synthetizes isopentyl, an important precursor of farnesyl (Table 2) [95]. In human endothelial cells, lovastatin inhibited Ras, Rho, and Rap prenylation [95]. Indolfi et al. used simvastatin, inhibiting Ras and preventing the development of left ventricular hypertrophy in rats with aortic banding [96].
However, both experiments needed a very high concentration of statins, a thousand and a hundred times higher respectively, than the dose used in hypercholesterolemia $[95,96]$. Finally, out of three clinical trials of Ras inhibition with lovastatin in patients with neurological deficits secondary to Ras-opathies, two suggested a modest benefit $[97,98]$, while a third did not find any significant effect after 16 weeks of treatment [99].

\section{Farnesyl transferase inhibitors (FTIs)}

These are a group of experimental anti-cancer drugs that block the farnesyl pyrophosphate synthase (FPPS), preventing the prenylation of Ras. FPPS inhibition in a transgenic mouse with a small interfering RNA (siRNA) of FPPS, resulted in inhibition of Ras activity and signaling pathway, with favorable effect on pressure overloadinduced cardiac remodeling [100]. Also, the farnesyl transferase inhibitor, FTI-276, improved cardiac remodeling in spontaneously hypertensive rats [101].

\section{Ras modulation by mRNA modulators}

A silencing inhibitor of RNA (siRNA) specific for H-Ras, si-H-Ras, inhibited rat cardiomyocytes hypertrophy

Table 2 Summary of Ras and Ras pathways modulators in the heart

\begin{tabular}{|c|c|c|c|}
\hline Group & Molecule & Mechanism of action & References \\
\hline \multirow[t]{2}{*}{ Inhibitors of Angiotensin-|| } & Candesartan & Angiotensin-\| AT1R receptor antagonist & $\begin{array}{l}\text { Established therapy of clinical cardiac } \\
\text { hypertrophy and HF }\end{array}$ \\
\hline & Captopril & $\begin{array}{l}\text { Angiotensin-converting enzyme (ACE) } \\
\text { inhibitor }\end{array}$ & $\begin{array}{l}\text { Established therapy of clinical cardiac } \\
\text { hypertrophy and HF }\end{array}$ \\
\hline \multirow[t]{4}{*}{ Inhibitors of Ras farnesylation } & Statins & $\begin{array}{l}\text { Inhibits synthesis of farnesyl by inhibition of } \\
\text { HMG-COA reductase }\end{array}$ & $\begin{array}{l}\text { Lipid lowering therapy with broad clinical } \\
\text { applications in cardiovascular prevention }\end{array}$ \\
\hline & Farnesyl transferase siRNA & Inhibits expression of farnesyl transferase & $\begin{array}{l}\text { Improves pressure overload cardiac remod- } \\
\text { eling in mice [100] }\end{array}$ \\
\hline & FPT-III & $\begin{array}{l}\text { Farnesyl analog: inhibits farnesylation of Ras } \\
\text { and other small GTPases }\end{array}$ & $\begin{array}{l}\text { Cardioprotective effect in ischemia-reper- } \\
\text { fusion related to ischemic pre-condition- } \\
\text { ing [90] }\end{array}$ \\
\hline & FTI-276 & Tetrapeptid-mimetic, which inhibits FPPS & $\begin{array}{l}\text { Improved cardiac remodeling in spontane- } \\
\text { ously hypertensive rats [101] }\end{array}$ \\
\hline Silencing-mRNA & si-RNA-H-Ras & Inhibits mRNA synthesis of H-Ras & $\begin{array}{l}\text { Inhibits cardiomyocyte hypertrophy in vitro } \\
\text { by phenylephrine [25] }\end{array}$ \\
\hline \multirow[t]{4}{*}{ Signal inhibitors } & Cyclosporin A & Calcineurin inhibitor & $\begin{array}{l}\text { Attenuates pressure overload cardiac } \\
\text { hypertrophy but causes HF [106] }\end{array}$ \\
\hline & Rapamycin & Akt inhibitor & $\begin{array}{l}\text { Prevented cardiac hypertrophy in a trans- } \\
\text { genic mouse model with SHP-2 active } \\
\text { mutation [107] }\end{array}$ \\
\hline & PD0325901 & MEK inhibitor & Tested in cancer patients [111] \\
\hline & SB203580 & p38 inhibitor & Only tested in cancer cells \\
\hline
\end{tabular}

Examples of molecules used to inhibit Ras and its pathways in the heart, experimentally in animal models or clinically in patients. To our knowledge, the anti-cancer molecules PD0325901 and SB203580 have not yet been used in cardiac diseases, but are of interest as inhibitors of Ras-related pathways (more details in paragraph 6 of the article) 
in vitro [25]. miR-378, an endogenous microRNA and negative regulator of cardiac hypertrophy, blocked cardiomyocyte hypertrophy, as well as phosphorylation of Akt and ERK1/2, by knocking down the expression of Grb2 [102], upstream to Ras (Fig. 1).

\section{Antibodies against Ras}

Recent experiments have shown that systemic administration of antibodies against Ras mutants exerted antitumor effects [103]. The antibodies against Ras used in experimental cancer therapy have a potential therapeutic effect in cardiovascular diseases, with high specificity and low toxicity [104].

\section{Regulation of other genes related to Ras}

Newly discovered molecules in the Ras pathways have potential therapeutic applications. Carabin, a Ras-GAP protein and negative regulator of pro-hypertrophic signaling molecules calcineurin and Ras, is a potential therapeutic target in cardiac hypertrophy and HF [45]. Another modulator of the Ras pathway is the Raf kinase inhibitor protein (RKIP), which allows a more beneficial activation of the $\beta$-adrenergic pathway, avoiding longterm adverse effects of $\beta$-adrenergic stimulation, such as arrythmias and ventricular remodeling [105].

\section{Regulation of Ras pathways with small molecules}

Other drugs have been used to counteract cardiac hypertrophy. For example, the immunosupresor Cyclosporine is a well-known inhibitor of calcineurin, and attenuates pressure-overload cardiac hypertrophy; however, it also causes HF, thus limiting its clinical use in that setting [106]. The macrolid Rapamycin, an immunosuppressant used in transplant, inhibits JNK and the Akt/mTOR complex, and prevented or even reversed cardiac hypertrophy in a transgenic mouse model with Ptpn11-Y279C that causes cardiac hypertrophy (Ptpn11 is a SHP2 protein, Fig. 1) [107]. Clinical trials in cancer patients with PDO325901, a specific MEK inhibitor, were terminated early due to ophthalmologic and neurologic toxicity [108].

\section{Conclusions and future directions}

The central role of Ras in pathologic and physiologic cardiac hypertrophy has been demonstrated in multiple in vitro and in vivo settings. Recent studies showing cardio-protective effects of H-Ras modulation [25, 43, 88, $100,101]$ open new therapeutic perspectives for pathological cardiac hypertrophy and HF.

Many questions remain, however, that deserve further studies. What specific pathways are activated by K-Ras and $\mathrm{H}$-Ras so that one leads to hyperplasia, while the other leads to hypertrophy? Is there a role for Ras modulation in established HF, outside of pathological hypertrophy leading to HF? In addition, many obstacles remain before specific clinical applications of Ras modulation can be envisioned in cardiology. The use of a transgene of Ras in patients carries the risk of activating oncogenes. Another challenge is the lack of specificity of the FTI to pathological cardiac hypertrophy.

Despite more than three decades of research, no effective pharmacologic inhibitor of Ras has reached the clinical arena. However, recent data from studies on cells and animal models are highly promising. The better appreciation of the complexities of the Ras signaling network, as well as technological advances, have renewed the enthusiasm for therapies targeting Ras in cardiac pathologies.

\begin{abstract}
Abbreviations
Akt: Protein Kinase B (PKB); Angll: Angiotensin II; ANF: Atrial Natriuretic Factor; AR: Adrenergic receptor; AT1R: Angiotensin-II receptor type 1; a1-AR: a1-Adrenergic receptor; $\beta$-AR: $\beta$-Adrenergic receptor; $\beta$-MHC: $\beta$-Myosin heavy chain; $\mathrm{Ca}^{++}$: Calcium; $\mathrm{CaMKIl:} \mathrm{Ca}^{++} /$calmodulin-dependent protein Kinase II; CAMP: Cyclic adenosine monophosphate; DAG: Diacylglycerol; DN-Ras: Dominant Negative Ras; eNOS: Endothelial nitric oxide synthase; Epac: Exchange protein directly activated by CAMP; ERK: Extracellular signal-regulated protein kinase; GAP: GTPase-activating protein; GDP: Guanosine Diphosphate; GEF: Guanine nucleotide exchange factor; GTP: Guanosine Triphosphate; G proteins: GTP-binding proteins; GPCR: G-protein coupled receptor; GSK: Glycogen Synthase Kinase; HCM: Hypertrophic cardiomyopathy; HF: Heart failure; HSG: Hyperplasia Suppressor $G e n e ; ~ I P_{3}$ : Inositol trisphosphate; $\mathrm{IP}_{3} \mathrm{R}$ : Inositol trisphosphate receptor; JNK: Jun $\mathrm{NH}_{2}$-terminal kinase; LEOPARD: Lentigines, Electrocardiographic conduction defects, Ocular hypertelorism, Pulmonary stenosis, Abnormalities of the genitalia, Retarded growth, Deafness; LTCC: L-type $\mathrm{Ca}^{++}$ channel; MAPK: Mitogen-Activated Protein Kinase; MEK: MAPKK (MAP kinase kinase) that activates a MAPK (ERK); NF1: Neurofibromin 1; NFAT: Nuclear Factor of Activated T cells; NF-kB: Nuclear Factor kappa B; PE: Phenylephrine; PDE: Phosphodiesterase; PI3K: Phosphoinositide 3-kinase; PIP2: Phosphatidylinositol 4,5-bisphosphate; PKA: Protein Kinase A; PKC: Protein Kinase C; PLC: Phospholipase C; PLN: Phospholamban; Ras: Rat sarcoma; Ras-opathies: Genetic diseases associated with mutations in the Ras pathway; RTK: Tyrosine Kinase receptor; RyR: Ryanodine receptor; SAPK: Stress Activated Protein Kinases; SEK-1: SAPK ERK kinase; SERCA: Sarcoplasmic reticulum $\mathrm{Ca}^{++}$ATPase; SkM- a Actin: Skeletal Muscle a Actin; Sos: Son of sevenless; TNF: Tumor Necrosis Factor.
\end{abstract}

\section{Acknowledgements}

We acknowledge the association Incluyendo México, A.C. for partial financial support.

\section{Authors' contributions}

MRK: He had the conception and design of the work, wrote the main body of the manuscript and coordinated the work of most co-authors. SHM: contributed to the section on the new Ras modulators: Epac, and Carabin, and wrote the section on Ras and arrhythmias. FSB: He collaborated in the design of the work and critical review of the manuscript. RJH: critical review of the draft. LL: substantially revised and critically reviewed the manuscript. ERC: Senior author; conception and design of the work, wrote large and important sections of the article. All authors read and approved the final manuscript.

\section{Funding}

Not applicable.

Availability of data and materials

Not applicable. 


\section{Declarations}

Ethics approval and consent to participate Not applicable.

\section{Consent of patients for publication}

Not applicable.

\section{Competing interests}

None.

\section{Author details}

'Instituto Nacional de Cancerología, Unidad de Investigación Biomédica en Cáncer, Secretarìa de Salud/Instituto de Investigaciones Biomédicas, Universidad Nacional Autónoma de México, Mexico City, México. ${ }^{2}$ Researcher of the Facultad de Bioética, Cátedra de Infertilidad, Universidad Anáhuac, Mexico City, México. ${ }^{3}$ Centro de Investigación en Bioética y Genética, Querétaro, México. ${ }^{4}$ Division of Nephrology, Department of Medicine, Jacobs School of Medicine and Biomedical Sciences, State University of New York at Buffalo, Clinical and Translational Research Center, 875 Ellicott Street, Suite 8030B, Buffalo, NY 14203, USA. ${ }^{5}$ University of Toronto Institute of Medical Science, Medical Sciences Building, 1 King's College Circle, Room 2374, Toronto, ON M5S 1A8, Canada. ${ }^{6}$ Phospholamban Foundation, Amsterdam, Netherlands. ${ }^{7}$ INSERM U955 and Département de Physiologie, Hôpital Henri Mondor, FHU SENEC, AP-HP, and Université Paris-Est Créteil (UPEC), 94010 Créteil, France.

Received: 15 January 2021 Accepted: 26 June 2021

Published online: 03 August 2021

\section{References}

1. Sala V, Gallo S, Leo C, Gatti S, Gelb BD, Crepaldi T. Signaling to cardiac hypertrophy: insights from human and mouse RASopathies. Mol Med. 2012;18:938-47.

2. Lezoualc'h F, Metrich M, Hmitou I, Duquesnes N, Morel E. Small GTPbinding proteins and their regulators in cardiac hypertrophy. J Mol Cell Cardiol. 2008;44(4):623-32.

3. Wennerberg K, Rossman KL, Der CJ. The Ras superfamily at a glance. J Cell Sci. 2005;118(Pt 5):843-6.

4. Prior IA, Lewis PD, Mattos C. A comprehensive survey of Ras mutations in cancer. Cancer Res. 2012;72(10):2457-67.

5. Thorburn A, Thorburn J, Chen SY, Powers S, Shubeita HE, Feramisco $J R$, et al. HRas-dependent pathways can activate morphological and genetic markers of cardiac muscle cell hypertrophy. J Biol Chem. 1993:268(3):2244-9.

6. Chien KR, Hoshijima M. Unravelling Ras signals in cardiovascular disease. Nat Cell Biol. 2004;6(9):807-8.

7. Gelb BD, Tartaglia M. RAS signaling pathway mutations and hypertrophic cardiomyopathy: getting into and out of the thick of it. J Clin Invest. 2011;121(3):844-7.

8. Lee KH, Hajjar RJ, Matsui T, Choukroun G, Force TL, Rosenzweig A. Cardiac signal transduction. J Nucl Cardiol. 2000;7(1):63-71.

9. Rose BA, Force T, Wang Y. Mitogen-activated protein kinase signaling in the heart: angels versus demons in a heart-breaking tale. Physiol Rev. 2010;90(4):1507-46.

10. Erijman A, Shifman JM. RAS/effector interactions from structural and biophysical perspective. Mini Rev Med Chem. 2016;16(5):370-5.

11. Petkova SB, Ashton A, Bouzahzah B, Huang H, Pestell RG, Tanowitz HB. Cell cycle molecules and diseases of the cardiovascular system. Front Biosci. 2000:5:D452-60.

12. Ramirez MT, Sah VP, Zhao XL, Hunter JJ, Chien KR, Brown JH. The MEKKJNK pathway is stimulated by alpha1-adrenergic receptor and ras activation and is associated with in vitro and in vivo cardiac hypertrophy. J Biol Chem. 1997:272(22):14057-61

13. Lei B, Schwinn DA, Morris DP. Stimulation of alpha1a adrenergic receptors induces cellular proliferation or antiproliferative hypertrophy dependent solely on agonist concentration. PLoS One. 2013;8(8):e72430
14. Duquesnes N Vincent F Morel E, Lezoualc'h F Crozatier B. The EGF receptor activates ERK but not JNK Ras-dependently in basal conditions but ERK and JNK activation pathways are predominantly Ras-independent during cardiomyocyte stretch. Int J Biochem Cell Biol. 2009:41(5):1173-81.

15. Jaalouk DE, Lammerding J. Mechanotransduction gone awry. Nat Rev Mol Cell Biol. 2009;10(1):63-73.

16. Chakrabarti M, Jang $H$, Nussinov R. Comparison of the conformations of KRAS isoforms, K-Ras4A and K-Ras4B, points to similarities and significant differences. J Phys Chem B. 2016;120(4):667-79.

17. Berns A. Kras and Hras-what is the difference? Nat Genet. 2008:40(10):1149-50.

18. Matallanas D, Arozarena I, Berciano MT, Aaronson DS, Pellicer A, Lafarga $M$, et al. Differences on the inhibitory specificities of $\mathrm{H}$-Ras, $\mathrm{K}$-Ras, and N-Ras (N17) dominant negative mutants are related to their membrane microlocalization. J Biol Chem. 2003;278(7):4572-81.

19. Cox AD, Fesik SW, Kimmelman AC, Luo J, Der CJ. Drugging the undruggable RAS: mission possible? Nat Rev Drug Discov. 2014;13(11):828-51.

20. Tham YK, Bernardo BC, Ooi JY, Weeks KL, McMullen JR. Pathophysiology of cardiac hypertrophy and heart failure: signaling pathways and novel therapeutic targets. Arch Toxicol. 2015;89(9):1401-38.

21. Dorn GW 2nd. The fuzzy logic of physiological cardiac hypertrophy. Hypertension. 2007:49(5):962-70.

22. McMullen JR, Jennings GL. Differences between pathological and physiological cardiac hypertrophy: novel therapeutic strategies to treat heart failure. Clin Exp Pharmacol Physiol. 2007;34(4):255-62.

23. Chemaly ER, Kang S, Zhang S, McCollum L, Chen J, Benard L, et al. Differential patterns of replacement and reactive fibrosis in pressure and volume overload are related to the propensity for ischaemia and involve resistin. J Physiol. 2013:591(21):5337-55.

24. Dhandapany PS, Fabris F, Tonk R, Illaste A, Karakikes I, Sorourian M, et al. Cyclosporine attenuates cardiomyocyte hypertrophy induced by RAF1 mutants in Noonan and LEOPARD syndromes. J Mol Cell Cardiol. 2011:51(1):4-15.

25. Ramos-Kuri M, Rapti K, Mehel H, Zhang S, Dhandapany PS, Liang L, et al. Dominant negative Ras attenuates pathological ventricular remodeling in pressure overload cardiac hypertrophy. Biochim Biophys Acta. 2015;1853(11 Pt A):2870-84.

26. Maillet M, van Berlo JH, Molkentin JD. Molecular basis of physiological heart growth: fundamental concepts and new players. Nat Rev Mol Cell Biol. 2013:14(1):38-48.

27. Zheng M, Dilly K, Dos Santos CJ, Li M, Gu Y, Ursitti JA, et al. Sarcoplasmic reticulum calcium defect in Ras-induced hypertrophic cardiomyopathy heart. Am J Physiol Heart Circ Physiol. 2004;286(1):H424-33.

28. Ho PD, Zechner DK, He H, Dillmann WH, Glembotski CC, McDonough PM. The Raf-MEK-ERK cascade represents a common pathway for alteration of intracellular calcium by Ras and protein kinase $C$ in cardiac myocytes. J Biol Chem. 1998:273(34):21730-5.

29. Gottshall KR, Hunter JJ, Tanaka N, Dalton N, Becker KD, Ross J $J r$, et al. Ras-dependent pathways induce obstructive hypertrophy in echo-selected transgenic mice. Proc Natl Acad Sci U S A. 1997:94(9):4710-5

30. Hunter JJ, Tanaka N, Rockman HA, Ross J Jr, Chien KR. Ventricular expression of a MLC-2v-ras fusion gene induces cardiac hypertrophy and selective diastolic dysfunction in transgenic mice. J Biol Chem. 1995:270(39):23173-8

31. Kai H, Muraishi A, Sugiu Y, Nishi H, Seki Y, Kuwahara F, et al. Expression of proto-oncogenes and gene mutation of sarcomeric proteins in patients with hypertrophic cardiomyopathy. Circ Res. 1998;83(6):594-601.

32. Wei BR, Martin PL, Hoover SB, Spehalski E, Kumar M, Hoenerhoff MJ, et al. Capacity for resolution of Ras-MAPK-initiated early pathogenic myocardial hypertrophy modeled in mice. Comp Med. 2011:61(2):109-18.

33. Koera K, Nakamura K, Nakao K, Miyoshi J, Toyoshima K, Hatta T, et al. K-ras is essential for the development of the mouse embryo. Oncogene. 1997;15(10):1151-9.

34. Hernandez-Porras I, Fabbiano S, Schuhmacher AJ, Aicher A, Canamero M, Camara JA, et al. K-RasV14I recapitulates Noonan syndrome in mice. Proc Natl Acad Sci U S A. 2014;111(46):16395-400. 
35. Matsuda T, Jeong JI, Ikeda S, Yamamoto T, Gao S, Babu GJ, et al. H-Ras isoform mediates protection against pressure overload-induced cardiac dysfunction in part through activation of AKT. Circ Heart Fail.2017 10(2):e003658. doi: https://doi.org/10.1161/CIRCHEARTFAILURE.116. 003658.

36. van Houdt WJ, de Bruijn MT, Emmink BL, Raats D, Hoogwater FJ, Borel Rinkes IH, et al. Oncogenic K-ras activates p38 to maintain colorectal cancer cell proliferation during MEK inhibition. Cell Oncol. 2010:32(4):245-57.

37. Cirstea IC, Kutsche K, Dvorsky R, Gremer L, Carta C, Horn D, et al. A restricted spectrum of NRAS mutations causes Noonan syndrome. Nat Genet. 2010;42(1):27-9.

38. Castellano E, Santos E. Functional specificity of ras isoforms: so similar but so different. Genes Cancer. 2011;2(3):216-31.

39. Hancock JF. Ras proteins: different signals from different locations. Nat Rev Mol Cell Biol. 2003;4(5):373-84

40. Esteban LM, Vicario-Abejon C, Fernandez-Salguero P, Fernandez-Medarde A, Swaminathan N, Yienger K, et al. Targeted genomic disruption of $\mathrm{H}$-ras and $\mathrm{N}$-ras, individually or in combination, reveals the dispensability of both loci for mouse growth and development. Mol Cell Biol. 2001;21(5):1444-52.

41. Nakamura K, Ichise H, Nakao K, Hatta T, Otani H, Sakagami H, et al. Partial functional overlap of the three ras genes in mouse embryonic development. Oncogene. 2008;27(21):2961-8.

42. Potenza N, Vecchione C, Notte A, De Rienzo A, Rosica A, Bauer L, et al. Replacement of K-Ras with $\mathrm{H}$-Ras supports normal embryonic development despite inducing cardiovascular pathology in adult mice. EMBO Rep. 2005;6(5):432-7.

43. Linglart L, Gelb BD. Congenital heart defects in Noonan syndrome: diagnosis, management, and treatment. Am J Med Genet C Semin Med Genet. 2020;184(1):73-80.

44. Sadoshima J, Izumo S. The heterotrimeric $\mathrm{G}$ q protein-coupled angiotensin II receptor activates p21 ras via the tyrosine kinase-Shc-Grb2-Sos pathway in cardiac myocytes. EMBO J. 1996;15(4):775-87.

45. Bisserier M, Berthouze-Duquesnes M, Breckler M, Tortosa F, Fazal L, de Regibus $A$, et al. Carabin protects against cardiac hypertrophy by blocking calcineurin, Ras, and Ca2+/calmodulin-dependent protein kinase II signaling. Circulation. 2015:131(4):390-400 (discussion).

46. Harrisingh MC, Lloyd AC. Ras/Raf/ERK signalling and NF1. Cell Cycle. 2004;3(10):1255-8.

47. Lakkis MM, Epstein JA. Neurofibromin modulation of ras activity is required for normal endocardial-mesenchymal transformation in the developing heart. Development. 1998;125(22):4359-67.

48. Petrich BG, Wang Y. Stress-activated MAP kinases in cardiac remodeling and heart failure; new insights from transgenic studies. Trends Cardiovasc Med. 2004;14(2):50-5.

49. Xu J, Ismat FA, Wang T, Lu MM, Antonucci N, Epstein JA. Cardiomyocytespecific loss of neurofibromin promotes cardiac hypertrophy and dysfunction. Circ Res. 2009;105(3):304-11.

50. Guellich A, Mehel H, Fischmeister R. Cyclic AMP synthesis and hydrolysis in the normal and failing heart. Pflugers Arch. 2014:466(6):1163-75.

51. Gwathmey JK, Yerevanian Al, Hajjar RJ. Cardiac gene therapy with SERCA2a: from bench to bedside. J Mol Cell Cardiol. 2011:50(5):803-12.

52. Laudette M, Zuo H, Lezoualc'h F, Schmidt M. Epac function and CAMP scaffolds in the heart and lung. J Cardiovasc Dev Dis. 2018;5(1):9.

53. Ulucan C, Wang X, Baljinnyam E, Bai Y, Okumura S, Sato M, et al. Developmental changes in gene expression of Epac and its upregulation in myocardial hypertrophy. Am J Physiol Heart Circ Physiol. 2007;293(3):H1662-72

54. Metrich M, Lucas A, Gastineau M, Samuel JL, Heymes C, Morel E, et al. Epac mediates beta-adrenergic receptor-induced cardiomyocyte hypertrophy. Circ Res. 2008;102(8):959-65.

55. Lipskaia L, Chemaly ER, Hadri L, Lompre AM, Hajjar RJ. Sarcoplasmic reticulum $\mathrm{Ca}(2+)$ ATPase as a therapeutic target for heart failure. Expert Opin Biol Ther. 2010;10(1):29-41.

56. Lipskaia L, Ly H, Kawase Y, Hajjar RJ, Lompre AM. Treatment of heart failure by calcium cycling gene therapy. Future Cardiol. 2007;3(4):413-23.

57. Molkentin JD. Calcineurin and beyond: cardiac hypertrophic signaling Circ Res. 2000;87(9):731-8.

58. Karnoub AE, Weinberg RA. Ras oncogenes: split personalities. Nat Rev Mol Cell Biol. 2008:9(7):517-31.
59. Lebeche D, Zhao Bin K, Hajjar R. Candesartan abrogates G proteincoupled receptors agonist-induced MAPK activation and cardiac myocyte hypertrophy. J Renin Angiotensin Aldosterone Syst. 2001;2(1_suppl):S154-61

60. Zhang GX, Kimura S, Murao K, Yu X, Obata K, Matsuyoshi H, et al. Effects of angiotensin type I receptor blockade on the cardiac Raf/ MEK/ERK cascade activated via adrenergic receptors. J Pharmacol Sci. 2010;113(3):224-33.

61. Chemaly ER, Hajjar RJ, Lipskaia L. Molecular targets of current and prospective heart failure therapies. Heart. 2013;99(14):992-1003.

62. Force T, Hajjar R, Del Monte F, Rosenzweig A, Choukroun G. Signaling pathways mediating the response to hypertrophic stress in the heart. Gene Expr. 1999;7(4-6):337-48.

63. Harris IS, Zhang S, Treskov I, Kovacs A, Weinheimer C, Muslin AJ. Raf-1 kinase is required for cardiac hypertrophy and cardiomyocyte survival in response to pressure overload. Circulation. 2004;110(6):718-23.

64. Yamaguchi O, Watanabe T, Nishida K, Kashiwase K, Higuchi Y, Takeda T, et al. Cardiac-specific disruption of the c-raf-1 gene induces cardiac dysfunction and apoptosis. J Clin Invest. 2004;114(7):937-43.

65. Choukroun G, Hajjar R, Fry S, del Monte F, Haq S, Guerrero JL, et al. Regulation of cardiac hypertrophy in vivo by the stress-activated protein kinases/c-Jun NH(2)-terminal kinases. J Clin Invest. 1999;104(4):391-8.

66. Aikawa R, Nagai T, Kudoh S, Zou Y, Tanaka M, Tamura M, et al. Integrins play a critical role in mechanical stress-induced p38 MAPK activation. Hypertension. 2002;39(2):233-8.

67. Murasawa S, Mori Y, Nozawa Y, Masaki H, Maruyama K, Tsutsumi Y, et al. Role of calcium-sensitive tyrosine kinase Pyk2/CAKbeta/RAFTK in angiotensin II induced Ras/ERK signaling. Hypertension. 1998;32(4):668-75.

68. Bayer AL, Heidkamp MC, Patel N, Porter MJ, Engman SJ, Samarel AM. PYK2 expression and phosphorylation increases in pressure overloadinduced left ventricular hypertrophy. Am J Physiol Heart Circ Physiol. 2002;283(2):H695-706

69. Ichida M, Finkel T. Ras regulates NFAT3 activity in cardiac myocytes. J Biol Chem. 2001;276(5):3524-30.

70. Aoyagi T, Matsui T. Phosphoinositide-3 kinase signaling in cardiac hypertrophy and heart failure. Curr Pharm Des. 2011;17(18):1818-24.

71. Wang L, Gout I, Proud CG. Cross-talk between the ERK and p70 S6 kinase (S6K) signaling pathways. MEK-dependent activation of S6K2 in cardiomyocytes. J Biol Chem. 2001;276(35):32670-7.

72. Wang L, Proud CG. Ras/Erk signaling is essential for activation of protein synthesis by Gq protein-coupled receptor agonists in adult cardiomyocytes. Circ Res. 2002;91(9):821-9.

73. Wang Y, Huang BP, Luciani DS, Wang X, Johnson JD, Proud CG. Rheb activates protein synthesis and growth in adult rat ventricular cardiomyocytes. J Mol Cell Cardiol. 2008;45(6):812-20.

74. Manning BD, Cantley LC. Rheb fills a GAP between TSC and TOR. Trends Biochem Sci. 2003:28(11):573-6.

75. Haq S, Choukroun G, Lim H, Tymitz KM, del Monte F, Gwathmey J, et al. Differential activation of signal transduction pathways in human hearts with hypertrophy versus advanced heart failure. Circulation. 2001;103(5):670-7.

76. Shimizu I, Minamino T, Toko H, Okada S, Ikeda H, Yasuda N, et al. Excessive cardiac insulin signaling exacerbates systolic dysfunction induced by pressure overload in rodents. J Clin Invest. 2010;120(5):1506-14.

77. Wende AR, O'Neill BT, Bugger H, Riehle C, Tuinei J, Buchanan J, et al. Enhanced cardiac Akt/protein kinase B signaling contributes to pathological cardiac hypertrophy in part by impairing mitochondrial function via transcriptional repression of mitochondrion-targeted nuclear genes. Mol Cell Biol. 2015;35(5):831-46.

78. Fiordelisi A, laccarino G, Morisco C, Coscioni E, Sorriento D. NFkappaB is a key player in the crosstalk between inflammation and cardiovascular diseases. Int J Mol Sci. 2019;20(7):1599.

79. Jhang WK, Choi JH, Lee BH, Kim GH, Yoo HW. Cardiac manifestations and associations with gene mutations in patients diagnosed with RASopathies. Pediatr Cardiol. 2016;37(8):1539-47.

80. Colquitt JL, Noonan JA. Cardiac findings in Noonan syndrome on longterm follow-up. Congenit Heart Dis. 2014;9(2):144-50.

81. Lin AE, Alexander ME, Colan SD, Kerr B, Rauen KA, Noonan J, et al. Clinical, pathological, and molecular analyses of cardiovascular abnormalities in Costello syndrome: a Ras/MAPK pathway syndrome. Am J Med Genet A. 2011;155A(3):486-507. 
82. Schulz AL, Albrecht B, Arici C, van der Burgt I, Buske A, GillessenKaesbach $\mathrm{G}$, et al. Mutation and phenotypic spectrum in patients with cardio-facio-cutaneous and Costello syndrome. Clin Genet. 2008;73(1):62-70

83. Sovik O, Schubbert S, Houge G, Steine SJ, Norgard G, Engelsen B, et al. De novo HRAS and KRAS mutations in two siblings with short stature and neuro-cardio-facio-cutaneous features. J Med Genet. 2007;44(7):e84.

84. Nguyen R, Mir TS, Kluwe L, Jett K, Kentsch M, Mueller G, et al. Cardiac characterization of 16 patients with large NF1 gene deletions. Clin Genet. 2013;84(4):344-9.

85. Kannel WB, Wolf PA, Benjamin EJ, Levy D. Prevalence, incidence, prognosis, and predisposing conditions for atrial fibrillation: populationbased estimates. Am J Cardiol. 1998;82(8A):2N-9N.

86. Psaty BM, Manolio TA, Kuller LH, Kronmal RA, Cushman M, Fried LP, et al. Incidence of and risk factors for atrial fibrillation in older adults. Circulation. 1997;96(7):2455-61.

87. Lau YF, Yiu KH, Siu CW, Tse HF. Hypertension and atrial fibrillation: epidemiology, pathophysiology and therapeutic implications. J Hum Hypertens. 2012;26(10):563-9.

88. Wang WW, Zhang FL, Chen JH, Chen XH, Fu FY, Tang MR, et al. Telmisartan reduces atrial arrhythmia susceptibility through the regulation of RAS-ERK and PI3K-Akt-eNOS pathways in spontaneously hypertensive rats. Can J Physiol Pharmacol. 2015;93(8):657-65.

89. Goette A, Staack T, Rocken C, Arndt M, Geller JC, Huth C, et al. Increased expression of extracellular signal-regulated kinase and angiotensinconverting enzyme in human atria during atrial fibrillation. J Am Coll Cardiol. 2000;35(6):1669-77.

90. Al-Rashdan I, Canatan H, Al-Maghrebi M, Yousif MH, Khan SA, Benter IF. Cardioprotection from ischemia-reperfusion injury due to Ras-GTPase inhibition is attenuated by glibenclamide in the globally ischemic heart. Cell Biochem Funct. 2007;25(4):455-61.

91. Kocsis GF, Pipis J, Fekete V, Kovacs-Simon A, Odendaal L, Molnar E, et al. Lovastatin interferes with the infarct size-limiting effect of ischemic preconditioning and postconditioning in rat hearts. Am J Physiol Heart Circ Physiol. 2008;294(5):H2406-9.

92. Virani SS, Alonso A, Benjamin EJ, Bittencourt MS, Callaway CW, Carson $A P$, et al. Heart disease and stroke statistics-2020 update: a report from the American Heart Association. Circulation. 2020;141(9):e139-596.

93. Yancy CW, Januzzi JL Jr, Allen LA, Butler J, Davis LL, Fonarow GC, et al. 2017 ACC expert consensus decision pathway for optimization of heart failure treatment: answers to 10 pivotal issues about heart failure with reduced ejection fraction: a report of the American College of Cardiology Task force on expert consensus decision pathways. J Am Coll Cardiol. 2018;71(2):201-30.

94. Xiong X, Yang X, Duan L, Liu W, Zhang Y, Liu Y, et al. Traditional Chinese medicine suppresses left ventricular hypertrophy by targeting extracellular signal-regulated kinases signaling pathway in spontaneously hypertensive rats. Sci Rep. 2017;7:42965.

95. Cho KJ, Hill MM, Chigurupati S, Du G, Parton RG, Hancock JF. Therapeutic levels of the hydroxmethylglutaryl-coenzyme A reductase inhibitor lovastatin activate ras signaling via phospholipase D2. Mol Cell Biol. 2011:31(6):1110-20

96. Indolfi C, Di Lorenzo E, Perrino C, Stingone AM, Curcio A, Torella D, et al. Hydroxymethylglutaryl coenzyme A reductase inhibitor simvastatin prevents cardiac hypertrophy induced by pressure overload and inhibits p21ras activation. Circulation. 2002;106(16):2118-24.
97. Bearden CE, Hellemann GS, Rosser T, Montojo C, Jonas R, Enrique $\mathrm{N}$, et al. A randomized placebo-controlled lovastatin trial for neurobehavioral function in neurofibromatosis I. Ann Clin Transl Neurol. 2016;3(4):266-79.

98. Mainberger F, Langer S, Mall V, Jung NH. Impaired synaptic plasticity in RASopathies: a mini-review. J Neural Transm (Vienna). 2016;123(10):1133-8.

99. Payne JM, Barton B, Ullrich NJ, Cantor A, Hearps SJ, Cutter G, et al. Randomized placebo-controlled study of lovastatin in children with neurofibromatosis type 1. Neurology. 2016;87(24):2575-84.

100. Zhao CZ, Zhao XM, Yang J, Mou Y, Chen B, Wu HD, et al. Inhibition of farnesyl pyrophosphate synthase improves pressure overload induced chronic cardiac remodeling. Sci Rep. 2016;6:39186.

101. Li X, Han J, Li L, Wang KJ, Hu SJ. Effect of farnesyltransferase inhibition on cardiac remodeling in spontaneously hypertensive rats. Int J Cardiol. 2013;168(4):3340-7.

102. Nagalingam RS, Sundaresan NR, Gupta MP, Geenen DL, Solaro RJ, Gupta M. A cardiac-enriched microRNA, miR-378, blocks cardiac hypertrophy by targeting Ras signaling. J Biol Chem. 2013;288(16):11216-32.

103. Shin SM, Choi DK, Jung K, Bae J, Kim JS, Park SW, et al. Antibody targeting intracellular oncogenic Ras mutants exerts anti-tumour effects after systemic administration. Nat Commun. 2017;8:15090.

104. Zhang J, Rabbitts TH. Intracellular antibody capture: a molecular biology approach to inhibitors of protein-protein interactions. Biochim Biophys Acta. 2014;1844(11):1970-6.

105. Lorenz K, Rosner MR, Brand T, Schmitt JP. Raf kinase inhibitor protein: lessons of a better way for beta-adrenergic receptor activation in the heart. J Physiol. 2017;595(12):4073-87.

106. Meguro T, Hong C, Asai K, Takagi G, McKinsey TA, Olson EN, et al. Cyclosporine attenuates pressure-overload hypertrophy in mice while enhancing susceptibility to decompensation and heart failure. Circ Res. 1999;84(6):735-40.

107. Marin TM, Keith K, Davies B, Conner DA, Guha P, Kalaitzidis D, et al. Rapamycin reverses hypertrophic cardiomyopathy in a mouse model of LEOPARD syndrome-associated PTPN1 1 mutation. J Clin Invest. 2011;121(3):1026-43.

108. Lorusso PM, Adjei AA, Varterasian M, Gadgeel S, Reid J, Mitchell DY, et al. Phase I and pharmacodynamic study of the oral MEK inhibitor Cl-1040 in patients with advanced malignancies. J Clin Oncol. 2005;23(23):5281-93.

109. Wu X, Simpson J, Hong JH, Kim KH, Thavarajah NK, Backx PH, et al. MEK-ERK pathway modulation ameliorates disease phenotypes in a mouse model of Noonan syndrome associated with the Raf 1(L613V) mutation. J Clin Invest. 2011;121(3):1009-25.

110. You X, Ryu MJ, Cho E, Sang Y, Damnernsawad A, Zhou Y, et al. Embryonic expression of $\operatorname{Nras}(G 12$ D) leads to embryonic lethality and cardiac defects. Front Cell Dev Biol. 2021;9:633661.

111. Baines AT, Xu D, Der CJ. Inhibition of Ras for cancer treatment: the search continues. Future Med Chem. 2011:3(14):1787-808.

\section{Publisher's Note}

Springer Nature remains neutral with regard to jurisdictional claims in published maps and institutional affiliations.

Ready to submit your research? Choose BMC and benefit from

- fast, convenient online submission

- thorough peer review by experienced researchers in your field

- rapid publication on acceptance

- support for research data, including large and complex data types

- gold Open Access which fosters wider collaboration and increased citations

- maximum visibility for your research: over 100M website views per year

At BMC, research is always in progress.

Learn more biomedcentral.com/submissions 